\title{
Shear Strength of Joints in Glued Laminated Timber: Normative Verification of Bibliography Results
}

\author{
Eduardo Chahud ${ }^{1}$, Vinicius Borges de Moura Aquino², Thiago Damasceno Silva ${ }^{2}$, Julia Naves Teixeira ${ }^{2}$, \\ André Luis Christoforo ${ }^{2, *}$, Francisco Antonio Rocco Lahr ${ }^{3}$
}

${ }^{1}$ Department of Civil Engineering, Federal University of Minas Gerais (UFMG), Belo Horizonte, Brazil
${ }^{2}$ Centre for Innovation and Technology in Composites - CITeC, Department of Civil Engineering (DECiv),
Federal University of São Carlos, São Carlos, Brazil
${ }^{3}$ Department of Structural Engineering (SET), University of Sao Paulo (EESC/USP), São Carlos, Brazil

\begin{abstract}
Wood has long been used by man for a wide range of purposes, including the production of furniture, civil construction and structural elements. Aiming the construction industry, the use of glued laminated timber proves to be an excellent alternative to constructive technology, allowing the production of elements with different shapes and sizes. It is important that the bonded wood presents resistance to the stresses imposed on its use. This way, the present study aims to make a comparative analysis of shear strength values of Glued Laminated Timber (also called glulam) through the analysis of studies done by several authors that used different types of wood and adhesives. The results found by these authors were verified based on the ASTM-D-5751 and the Brazilian standard ABNT NBR 7190. It was concluded that the glued joints analyzed obtained satisfactory resistance according to the American standard. However, the majority did not comply with the parameters required by the Brazilian standard.
\end{abstract}

Keywords Wood, Glued Laminated Timber, Adhesives, Shear Strength

\section{Introduction}

Wood, since ancient times, has been used in civil construction on structural purpose or as a revetment. Formerly, most of wood parts used were from hardwood wood species and still nowadays it is possible to observe such parts on ancient houses, farms, railway sleepers, and even planks, demonstrating its great durability. Presently, the wood use has been preponderantly done through reforestation wood specie such as Pinus and Eucalyptus, which can be observed in great planting areas in Brazil [1].

The reconstituted wood products presents uncounted advantages when compared with solid wood in dimensions, dimensional stability, and better distribution of mechanical strength. Its use is wide, with applications on furniture and packaging industry, also on civil construction [2].

Among the reconstituted wood products and the reforestation woods, it has excelled the gluing of wood thin layers to build robust parts and with strength which fits on several projects and on structural demands. According Iwakiri et al. [2], from gluing small wood parts, it can be

* Corresponding author:

alchristoforo@gmail.com (André Luis Christoforo)

Published online at http://journal.sapub.org/ijme

Copyright $\odot 2018$ The Author(s). Published by Scientific \& Academic Publishing This work is licensed under the Creative Commons Attribution International License (CC BY). http://creativecommons.org/licenses/by/4.0/ reached a new product with a major added value and possibilities an efficient use of forest resources.

Glued Laminated Timber (GLT) can be defined as a composed material made of small wood parts, smaller than the original wood, united by the adhesive, presenting the layers fibers parallel to the part length [3].

To achieve the adhesion between wood layers, it is necessary the utilization of a binder or adhesive. The adhesives for gluing wood has its main components of formulation components derivate from petroleum, which displays excellent adhesion properties [4].

The formation of the glue line and the quality of adhesive link depends on the chemical properties of the glue and the wood (viscosity, for example), physical and structural properties of the adhesive, wood physical and structural properties (mechanical properties, wood density and porosity, for example) [5]. Also, the type of glue, the curing time and gluing pressure are factor which influence on the collage [6].

The glued joints confection becomes necessary to obtain parts of demanded dimensions by the market or even get rid of some defects on wood, as the knot presence [7].

Considering the exposed, this research intend to perform a review about the utilization of different types of adhesive and woods used on glued laminated timber regarding shear strength by obtained results in other studies when compared to the minimum shear strength required by the American and Brazilian standards. 


\section{Material and Methods}

\subsection{Adhesives}

According Passos et al. [8] the use of adhesive may represent up to 50\% of GLT price when compared with solid wood. Conform Gonçalves et al. [7], the petroleum composites, which contains excellent adhesion properties, are the main elements on glue formulation.

On the analyzed researches, several types of adhesives had been used to glue wood joints. The adhesives used were the polyvinyl acetate (PVA), resorcinol-phenol-formaldehyde (RFF), isocyanate polymeric emulsions (EPI), tannin formaldehyde (TF), urea formaldehyde (UF), melamine urea formaldehyde (MUF) and the mammon oil based polyurethane.

The PVA is produced through the polymerization of vinyl acetate monomer. Despite the glued products with PVA presents limitations about the use on elevated temperatures and elevated moisture, this adhesive has elevated mechanical strength on dry ambient [9].

The resorcinol-phenol-formaldehyde adhesive, according Pizzi [9], is used on glulam parts manufacturing, boats constructions, airplanes, on adverse conditions of temperature and moisture parts assembly. The resorcinol is more reactive than the phenol, which is a low cost phenol substance.

The EPI is an adhesive composed by two components and then, called bicomponent. They are the poli base (vinyl acetate) and a polymeric isocyanate (diphenylmethane-diisocyanate-MDI), resistant to high temperatures, water and solvents. It displays good stability, rapid curing, flexible, but more expensive when compared with PVA [10].

The resorcinol-formol (RF) based adhesive produce joints resistant to cold and hot water immersion, and owns the advantages of cold curing and it is similar to phenol resins, being used on naval and GLT manufacturing [11].

The UF adhesive is a tridimensional polymer obtained from urea and formaldehyde heating. This material presents limited moisture resistance [12]. Its use is advantageous due its low cost and it is classified for inner use [2].

Tannin formaldehyde glue is an adhesive produced from natural polyphenol extracted from tree bark or wood of acacias. It has been used in Africa and Germany since 1970, gained market share during the petroleum crisis. One if its main characteristics is the collage resistant to moisture, which enables the use of manufactured panel on external areas [13].

Melamine Urea Formaldehyde (MUF) is a thermofixed resin based glue. It displays good mechanical strength and low moisture resistance, classified for inner use [14].

\subsection{Glued Joints Strength Determination Test}

According Pinto [15], on the structural system constituted by glulam timber the strength is given on timber-adhesive interface. The author affirms that the stresses generated on glue interface manifest themselves through shear stresses perpendicular on the adhesive link plan. The glue applied unite the subtracts and fulfill the voids on the link, standardizing the structure. The glued link strength are measured by the glued joint shear strength determination test.

Following the Brazilian Standard ABNT NBR 7190 [16] the glued joint shear strength must be at least the wood shear strength along the grain. In the Annex B of the referred standard is described the tests to determine physical and mechanical properties in woods. The American Standard ASTM-D-5751 [17] defines the average shear strength on glued joint must be a minimum of $60 \%$ of wood strength [7].

\section{Results and Discussion}

\subsection{Discussion}

Iwakiri et al. study [18] aimed to evaluate the quality of glued joints of Eucaliptus benthamii wood, medium density equals to $0.687 \mathrm{~g} / \mathrm{cm}^{3}$, in different collage interfaces using PVA and RFF adhesives.

The wood utilized on the research has been unfolded in tangential and radial cuts and dried at $12 \%$ moisture. The parts were glued in three faces: tangential/tangential (T/T); radial/radial $(\mathrm{R} / \mathrm{R})$ and Tangential/Radial, varying the adhesive, obtaining six combinations at all.

The mean shear strength values on glued joints with RFF and PVA on T/T, R/R and T/R faces varied between 6.89 to $9.44 \mathrm{MPa}$, with the higher absolute average was obtained for PVA glued joints on T/T interface and the lower average, for RFF glued joints on $R / R$ interface.

Conform Iwakiri et al. [18], the PVA glued joints presented the average shear strength value higher when compared with RFF glued joints. Besides, the T/T glued joints displayed an elevated shear strength.

In 2016, Gonçalves et al [7] studied the strength of three boards of Pinus sp. wood glued with PVA, TF, UF, MUF and EPI adhesives, with grammage of $300 \mathrm{~g} . \mathrm{m}^{-2}$, acquired in Brazilian state of Espírito Santo. The timber has been unfolded in lamellas of $19 \times 60 \times 31 \mathrm{~mm}$ and glued after 15 days drying on chamber at $25^{\circ} \mathrm{C}$ and $25 \%$ moisture. With this experience, the authors researched the shear strength on Pinus sp. boards glued at room temperature [7].

For this experiment, wood parts passed by natural drying for three months. In addition, wood was characterized with $2 \times 2 \times 3 \mathrm{~cm}$ test proofs, evaluating basic density, shear strength (normal and parallel to the grain). Adhesive $\mathrm{pH}$, viscosity and density were analyzed.

The variation between wood densities was small, considering a heterogenic material. Additionally, there was no great discrepancy on shear strength (parallel and normal to the grain) values, with values higher than ones disposed on Brazilian Standard [16] (4 to $6 \mathrm{MPa}$ ) for this wood specie. About the adhesives, UF displayed the best properties.

The GLT shear strength results demonstrated that the 
proof test fixed with PVA, UF, MUF adhesives presented major strengths, with no significant difference between them. EPI glued timber performance remained on the average limit imposed by the ASTM-D-5751 standard [17] (4.66 MPa), which corresponds to $60 \%$ of Pinus sp. solid wood strength. The worst performance was verified on TF glued proof test, which results were above the limit disposed on the standard [17].

Chahud et al. [19] researched the behavior of shear stresses on glue interface and shear strength on solid wood using Resorcinol-Phenol based adhesive for eight wood species sold in metropolitan region of Brazilian city of Belo Horizonte. The tests were performed for each wood specie, proof test were selected from parts with no defects. Wood species tested were: Andiroba (Carapa Guianensis), Angelim (Hymenolobium spp.), Cedro (Cedrella fissilis), Cumarí (Dipteryx odorata), Ipê (Tabebuia spp.), Piquiarana (Caryocar microcarpum), Roxinho (Peltogyne confertiflora) e Vinhático (Plathymenia reticulata).

In the first test, it was determined shear strength parallel to the grain, following the disposed on the Brazilian Standard ABNT NBR 7190 [16], determining the main shear strength for each wood specie. The second test used the RF adhesive for proof test collage and then, after curing time determined by glue manufacturer, it was tested, resulting the shear strength on adhesive interface for each wood specie. During evaluation, apparent density was determined at $12 \%$ moisture.

According Chahud [19], even the high density wood species Andiroba and Angelim showed a good performance on collage and they did not presented shear strength on solid wood comparable with Ipê and Cumaru wood species on glued version.

Cedro, Ipê, Cumaru and Roxinho wood species displayed on shear strength on glued proof test lower than solid wood, respectively, discarding the equalization hypothesis of shear strength for both tested wood species.
Andiroba, Angelim, Piquirana and Vinhático wood species, on glued proof test demonstrate shear strength near to solid test proof strength, enabling the use of these wood species on GLT observing only shear strength.

Iwakiri et al. [2] evaluated the quality of glued joints of Cryptomeria japonica and Sequoia sempervirens wood species using PVA and EPI adhesives on 150 and $200 \mathrm{~g} / \mathrm{m}^{2}$ grammage. Following the EN 13354/2003 standard [20], twenty proof test were made for shear test on glue interface. Ten proof test were used for tests with no pre-treatment (proof test stored at $20 \pm 3^{\circ} \mathrm{C}$ and relative moisture equals to $65 \pm 5 \%$ ) and the other 10 proof test were pre-treated with water immersion at $20^{\circ} \mathrm{C}$ temperature for 24 hours, for final use on dry environment.

Joints with no pre-treatment indicated the higher main shear strength value of $10.51 \mathrm{MPa}$, on glued joints of sequoia using EPI adhesive and $200 \mathrm{~g} / \mathrm{m}^{2}$ grammage, and the lower average shear strength, $1.92 \mathrm{MPa}$, for glued joints of Crytomeria/sequoia with PVA adhesive and $200 \mathrm{~g} / \mathrm{m}^{2}$ grammage.

Tests applied on glued joints with pre-treatment indicated the major average shear strength, $5.92 \mathrm{MPa}$, on sequoia glued joints with EPI adhesive and $150 \mathrm{~g} / \mathrm{m}^{2}$ grammage. The minor average value, $1.92 \mathrm{MPa}$, was obtained for Cryptomeria and sequoia glued joints with PVA adhesive and $200 \mathrm{~g} / \mathrm{m}^{2}$ grammage.

Considering the adhesives the authors concluded that EPI glued joints displayed a medium statistically superior to PVA glued joints. Then, the EPI glue is the most indicated for GLT parts manufacturing which requires humidity resistance.

\subsection{Results}

On Table 1 it is displayed a resume about the obtained results by the authors analyzing shear strength on respective wood species and adhesives.

Table 1. Resume of Shear Strength Results Obtained on Previous Researches

\begin{tabular}{|c|c|c|c|}
\hline Author & Wood Specie & Adhesive & Shear Strength on Glued Joint (MPa) \\
\hline \multirow{2}{*}{ Iwakiri et al [18] } & \multirow{2}{*}{ Eucalypitus benthamii } & PVA & 9,44 \\
\hline & & RFF & 6,89 \\
\hline \multirow{5}{*}{ Gonçalves et al [7] } & \multirow{5}{*}{ Pinus sp. } & PVA & 8,95 \\
\hline & & UF & 8,99 \\
\hline & & $\mathrm{TF}$ & 3,69 \\
\hline & & EPI & 4,86 \\
\hline & & MUF & 9,58 \\
\hline \multirow{8}{*}{ Chahud et al [19] } & Andiroba (Carapa Guianensis) & \multirow{8}{*}{ RFF } & 12,35 \\
\hline & Angelim (Hymenolobium spp.) & & 11,42 \\
\hline & Cedro (Cedrella fissilis) & & 5,91 \\
\hline & Cumarí (Dipteryx odorata) & & 13,97 \\
\hline & Ipê (Tabebuia spp.) & & 13,70 \\
\hline & Piquiarana (Caryocar microcarpum) & & 10,08 \\
\hline & Roxinho (Peltogyne confertiflora) & & 10,45 \\
\hline & Vinhático (Plathymenia reticulata) & & 7,47 \\
\hline
\end{tabular}




\begin{tabular}{|c|c|c|c|}
\hline Author & Wood Specie & Adhesive & Shear Strength on Glued Joint (MPa) \\
\hline \multirow{12}{*}{ Iwakiri et al [2] } & \multirow{2}{*}{ Cryptomeria japonica } & PVA & 8,04 \\
\hline & & EPI & 8,16 \\
\hline & \multirow{2}{*}{ Sequoia sempervirens } & PVA & 9,03 \\
\hline & & EPI & 10,51 \\
\hline & \multirow{2}{*}{ Cryptomeria/Sequoia } & PVA & 9,43 \\
\hline & & EPI & 8,64 \\
\hline & \multirow{2}{*}{ Cryptomeria japonica (with treatment) } & PVA & 2,26 \\
\hline & & EPI & 4,73 \\
\hline & \multirow{2}{*}{ Sequoia sempervirens (with tratment) } & PVA & 2,40 \\
\hline & & EPI & 5,51 \\
\hline & \multirow{2}{*}{ Cryptomeria/Sequoia (with tratment) } & PVA & 1,96 \\
\hline & & EPI & 4,43 \\
\hline
\end{tabular}

Obs.: Iwakiri et al. [2] present shear strength for $200 \mathrm{~g} / \mathrm{m}^{2}$ grammage.

Table 2 shows a comparative relation between analyzed researches. The studies were verified by the American Standard ASTM-D-5751 [17] and by Brazilian Standard ABNT NBR 7190 [16] about GLT parts quality.

Table 2. Glued Joints Shear Strength Analysis under ASTM and NBR Standards

\begin{tabular}{|c|c|c|c|c|c|c|}
\hline Wood Specie & Adhesive & $\begin{array}{c}\text { Shear Strength } \\
\text { on Glued Joint } \\
\text { (MPa) }\end{array}$ & $\begin{array}{l}\text { Shear Strength on } \\
\text { Wood (MPa) }\end{array}$ & $\begin{array}{l}\text { 60\% Shear } \\
\text { Strength } \\
\text { (ASTM) }\end{array}$ & $\begin{array}{c}\text { Verification } \\
\text { according } \\
\text { ASTM }\end{array}$ & $\begin{array}{c}\text { Verification } \\
\text { according } \\
\text { NBR }\end{array}$ \\
\hline \multirow{2}{*}{ Eucalypitus benthamii } & PVA & 9,44 & \multirow{2}{*}{$\begin{array}{l}\text { 11,41 (Miller et al, } \\
{[20] \text { ) }}\end{array}$} & \multirow{2}{*}{6,85} & $\mathrm{OK}$ & NOT OK \\
\hline & RFF & 6,89 & & & OK & NOT OK \\
\hline \multirow{5}{*}{ Pinus sp. } & PVA & 8,95 & \multirow{5}{*}{$\begin{array}{l}\text { 7,77 (Parallel) 8,08 } \\
\quad \text { (Perpendicular) }\end{array}$} & \multirow{5}{*}{4,66} & OK & OK \\
\hline & UF & 8,99 & & & OK & $\mathrm{OK}$ \\
\hline & $\mathrm{TF}$ & 3,69 & & & NOT OK & NOT OK \\
\hline & EPI & 4,86 & & & $\mathrm{OK}$ & NOT OK \\
\hline & MUF & 9,58 & & & OK & OK \\
\hline Andiroba (Carapa Guianensis) & \multirow{8}{*}{ RFF } & 12,35 & 13,63 & 8,18 & OK & NOT OK \\
\hline Angelim (Hymenolobium spp.) & & 11,42 & 11,94 & 7,16 & OK & NOT OK \\
\hline Cedro (Cedrella fissilis) & & 5,91 & 8,29 & 4,97 & Ok & NOT OK \\
\hline Cumarí (Dipteryx odorata) & & 13,97 & 20,53 & 12,32 & OK & NOT OK \\
\hline Ipê (Tabebuia spp.) & & 13,70 & 20,38 & 12,23 & OK & NOT OK \\
\hline $\begin{array}{l}\text { Piquiarana (Caryocar } \\
\text { microcarpum) }\end{array}$ & & 10,08 & 11,96 & 7,18 & OK & NOT OK \\
\hline Roxinho (Peltogyne confertiflora) & & 10,45 & 22,92 & 13,75 & OK & NOT OK \\
\hline $\begin{array}{c}\text { Vinhático (Plathymenia } \\
\text { reticulata) }\end{array}$ & & 7,47 & 8,84 & 5,30 & OK & NOT OK \\
\hline \multirow{2}{*}{ Cryptomeria japonica } & PVA & 8,04 & 7,58 (Hong et al [21]) & 4,548 & OK & OK \\
\hline & EPI & 8,16 & 7,58 & 4,548 & OK & OK \\
\hline \multirow[t]{2}{*}{ Sequoia sempervirens } & PVA & 9,03 & $\begin{array}{c}\text { 1,5 (Material Property } \\
\text { Data [22]) } \\
\end{array}$ & 0,9 & OK & OK \\
\hline & EPI & 10,51 & 1,5 & 0,9 & OK & OK \\
\hline \multirow{2}{*}{ Cryptomeria/Sequoia } & PVA & 9,43 & 1,5 & 0,9 & OK & OK \\
\hline & EPI & 8,64 & 1,5 & 0,9 & OK & OK \\
\hline \multirow{2}{*}{$\begin{array}{c}\text { Cryptomeria japonica (With } \\
\text { Treatment) }\end{array}$} & PVA & 2,26 & 7,58 & 4,548 & NOT OK & NOT OK \\
\hline & EPI & 4,73 & 7,58 & 4,548 & $\mathrm{OK}$ & NOT OK \\
\hline \multirow{2}{*}{$\begin{array}{c}\text { Sequoia sempervirens (With } \\
\text { Treatment) }\end{array}$} & PVA & 2,40 & 1,5 & 0,9 & OK & OK \\
\hline & EPI & 5,51 & 1,5 & 0,9 & OK & OK \\
\hline \multirow{2}{*}{$\begin{array}{c}\text { Cryptomeria/Sequoia (with } \\
\text { treatment) }\end{array}$} & PVA & 1,96 & 1,5 & 0,9 & $\mathrm{OK}$ & OK \\
\hline & EPI & 4,43 & 1,5 & 0,9 & OK & OK \\
\hline
\end{tabular}


Considering the disposed on Table 2, handling the American Standard, only Pinus sp.wood specie with TF adhesive and Cryptomeria japonica wood specie with PVA adhesive did not reached satisfactory strength. Observing the Brazilian Standard, which establishes the glued joint strength must be at least the shear strength of solid wood, many samples did not displayed adequate shear strength, as: Eucalypitus benthamii, Pinus sp. with TF and EPI adhesive, Andiroba (Carapa Guianensis), Angelim (Hymenolobium spp.), Cedro (Cedrella issilis), Cumarí (Dipteryx odorata), Ipê (Tabebuia spp.), Piquiarana (Caryocar microcarpum), Roxinho (Peltogyne confertiflora), Vinhático (Plathymenia reticulata), Cryptomeria japonica (with treatment).

\section{Conclusions}

Joints, made from Glued Laminated Timber, are big allies on civil construction and shear strength analysis of these parts are important for their utilization. Considering several researches performed by many authors, it was able to observe many wood species on glued joint with adequate shear strength using different types of adhesives.

Observing the American Standard [17], only two wood species, Pinus sp. and Cryptomeria japonica, did not presented enough shear strength.

The Brazilian Standard [16] indicates the shear strength of glued joints should be at least the solid wood shear strength. Following the disposed, many glued joints have not displayed enough strength, however, it is possible to use determined wood specie if wood strength met with the demanded on the project. The standard requirement aims material economy. If GLT displays shear strength lower than solid wood, its utilization may be less advantageous.

\section{ACKNOWLEDGMENTS}

For all the provided support, the authors thanks the Coordenação de Aperfeiçoamento de Nível Superior (CAPES) and the Conselho Nacional de Desenvolvimento Científico e Tecnológico (CNPq).

\section{REFERENCES}

[1] Leal, U. O potencial das madeiras de reflorestamento. Téchne, São Paulo, v. 1, n. 70, p.1-3, jan. 2003. Available on: $<$ http://techne.pini.com.br/engenharia-civil/70/artigo2852551. $\operatorname{aspx}>$. Access on: 10 jun. 2017.

[2] Iwakiri, S.; Trianoski, R.; França, R. F.; Gonçalves, T. A. P.; Loiola, P. L.; Campelo, S. R.; Farias, S. M. A. P. Avaliação da resistência de juntas coladas da madeira de Cryptomeria japônica e Sequoia semprevirens com diferentes adesivos. Scientia Florestalis. V. 43, n. 105, p. 19-26, mar. 2015.

[3] Moi, S. V.; Petrauski, S.M.F.C.; Petrauski, A. Desempenho de juntas estruturais em Madeira Laminada Colada de eucalipto utilizando adesivos Resorcinol e Mamona. In Congresso Técnico e Científico da Engenharia e da Agronomia - CONTECC 2016 - Foz do Iguaçu, Paraná, Brasil. 2016.

[4] Tienne, D. L. C.; Nascimento, A. M.; Garcia, R.A.; Silva, D. B. Qualidade de adesão de juntas de madeira de Pinus coladas em condições simuladas de serviço interna e externa. Floresta e Ambiente, Seropédica, v. 18, n. 1, p. 16-29, 2011.

[5] Follrich, J.; Teischinger, A.; Gindl, W.; Müller, U. Effect of grain angle on shear strength of glued end grain to flat grain joints of defect-free softwood timber. Wood Science and Technology, v. 41, p. 501-509, 2007.

[6] Nascimento, A. M.; Garcia, R. A.; Della Lucia, R. M. Qualidade de adesão de juntas coladas de diferentes espécies comerciais de madeira. Cerne, v. 19, n. 4, p. 593-601, 2013.

[7] Gonçalves, F. G.; Segundinho, P. G. de A.; Schayder, L. F.; Tinti, V. P.; Santiago, S. B. Avaliação da resistência ao cisalhamento da madeira de Pinus sp coladas em temperatura ambiente. Ciência da Madeira (Brazilian Journal of Wood Science), p. 42-50. 2016.

[8] Passos, O. S.; Lobo, J. B. A.; Ventura, O. S. P.; Fujiyama, R. T. Estudos preliminares de juntas de madeira-madeira coladas com material polimérico: superfície de fratura. In: Congresso Brasileiro de Engenharia e Ciência dos Materiais, 17, 2006, Foz do Iguaçu. Anais... São Paulo: IPEN, 2006, p. 8843-8854.

[9] Pizzi, A. Wood adhesives: Chemistry and Technology. New York: Marcel Dekker, 1983. 364p.

[10] Frihart, C. R.; Hunt, C. G. Adhesives with Wood Materials Bond Formation and Performance. Wood Handbook - Wood as an engineering material. Madison, cap. 10, p. 1-24, 2010.

[11] Albino, V. C. S. Estudo do comportamento da colagem da madeira de Eucalyptus grandis W. Hill ex Maiden com adesivo termo endurecedor resorcinol-formaldeído. Dissertação - UFLA, Lavras/MG, 2009.

[12] Mendes, R. F., Mendes, L. M., Jr. Guimarães, J. B., Santos, R. C., César, A. A. S. Efeito da associação de bagaço de cana, do tipo e do teor de adesivo na produção de painéis aglomerados. Ciência Florestal, Santa Maria, v. 22, n. 1, p. 161-170, jan.- mar., 2012.

[13] Teodoro, Â. S. Utilização de adesivos à base de taninos na produção de painéis de madeira aglomerada e OSB. 2007. 91 f. Dissertação (Mestrado em Ciências Ambientais e Florestais). Instituto de Florestas, Departamento de Produtos Florestais, Universidade Federal Rural do Rio de Janeiro, Seropédica, RJ, 2008.

[14] Iwakiri, S.; Andrade, A. S.; JR. Cardoso, A. A.; Chipanski, E. R.; Prata, J. G.; Adriazola, M. K. O. Produção de painéis aglomerados de alta densificação com uso de resina melamina-uréia-formaldeído., Cerne, Lavras, v. 11, n. 4, p. 323-328, out./dez. 2005.

[15] Pinto, J. A. Análise da viabilidade do uso da madeira de "Cryptomeria japonica" para laminação e produção de painéis compensado. 2011. 101 p. Dissertation (Mestrado em Ciências Florestais) - Universidade Federal do Paraná, Curitiba, 2011.

[16] Associação Brasileira de Normas Técnicas. NBR 7190: 
Projeto de estruturas de madeira. Rio de Janeiro, 1997. 107p.

[17] American Society for Testing and Materials. D-5751: Adhesives used for laminate joints in nonstructural lumber products. West Conshohocken, PA, 2005. 11p.

[18] Iwakiri, S.; Matos, J. L. M.; Prata, J. G. Evaluation of the use potential of nine species of genus Eucalyptus for production of veneers and plywood panels. CERNE (UFLA), v. 19, p. 263-269, 2013.

[19] Chahud, E.; Rocco, F. A. L.; Peres, R. R. O uso de espécies nativas comercializadas em Belo Horizonte na composição de madeira laminada colada. Revista Construindo, Belo Horizonte. Volume 01, n.2, p.46-49. Julho/Dez., 2009.
[20] Muller, B. V., Rocha, M.P., Cunha, A. B., Klitzke, R. J., Nicolletti, M. F. Avaliação das Principais Propriedades Físicas e Mecânicas da Madeira de Eucalyptus benthamii Maiden et Cambage. Floresta e Ambiente. V. 21, p. 535-542, 2014.

[21] Hong, N.; Won, K.; Yoo, B.; Jung, S.; Byeon, H. Mechanical Properties of Cryptomeria japonica by the Differences of Stand Characteristics in Southern Region of Korea. Korean Science. V. 43, p.320-326, 2015.

[22] Material Property Data (United States of America) (Org.). Matweb: Material Property Data. Available at: <http://www.matweb.com>. Acesso em: 14 jun. 2017. 